Ann. Génét. Sél. anim., I97I, 3 (I), 7 I-83.

\title{
THE EFFECT OF SIZE AND TYPE UPON THE EFFICIENCY OF MILK AND BEEF PRODUCTION IN CATTLE*
}

\author{
A. HORN, S. BOZÓ et A. DUNAY \\ Chair of Animal-Husbandry, \\ Research Institute for Animal Breeding, \\ Cattle-Breeding Department, \\ University of Veterinary Science, \\ Rottenbiller $u$. 23-25 \\ Budapest VII Hungary
}

\section{SUMMARY}

Partly on the basis of their investigation and of synthetising data of the professional literature the authors have analyzed the correlation and effects of the body size and of some other grading characters of cattle in relation to the production of products by whole populations.

According to their examinations the efficiency of size of the individual production is not always characteristic for the trend in the productivity of the total population. Thus e.g. the selection aiming at a larger daily gain, which is advantageous for the feed conversion of the individual, may lead to the development of a cow stock of a large body weight, which may decrease the quantity of beef (calfs) and of milk which can be produced on the identic quantity of nutrients.

Examining the relation of body size and milk-yield in populations producing under the same environmental conditions -in contradiction with most earlier examinations- within the breed there is no conspicuous correlation between the two characters according to the more recent results of researches. Similarly a substantial reciprocity - within the breed-between the body size of parents and beef-production of their progenies cannot be demonstrated either. The probable cause of this is that within the breed the different live weights are not separated genetically. On the ground of all these over a certain limit no meritorious and rational increase of beef-, nor the milk production can be expected from the increase of body size.

While in relation to milk-production the influences of the individual characters (milk quantity, butterfat and protein contents etc.) on the individual and population production are relatively clarified, the situation is more intricate

(*) Paper presented in the Study Meeting of the European Association for Animal Production, Genetic Commission, Gödöllö, Ausgut 28th, r97o. 
in relation to beef-production. The beef production of cattle and particularly its efficiency is a function of a very large number of characters. The selection aiming at the improvement of grading characters typical for the individual (daily growth rate, feed convention, carcase percentage, beef-conformation, beefquality, etc.) do not enhance unequivocally the increase of the beef producing capacity of the total population. The latter is determined by the maintenable cow number and fertility indices in the first place.

The selection at milk-production can be with great difficulties brought in harmony practically with the simultaneous improvement of the beef production, moreover the increase in the milk yield per cow in case of dual-purposebreeds does not allow alone in itself that milk - and beef production structures corresponding to the market demands be formed.

The breeding method suggested by the authors seems useful for a simultaneous rational increase of beef production relative to milk. The main point of this is the performance of utility cross-breeding with early maturing beefbreed bulls in sexually early maturing cow populations of the dairy type. The born bulls are marketed after fattening, while heifers of beef breed paternity are fertilized at young age - similarly with beef bulls - and after one month following the calving is marketed for slaughter as a young cow. After the beginning of full rotation - with the calving of the beef-purpose heifers- the live weight of the produced young beef animal marketable after one dairy cow grows with 44 per cent, against an additionnal I4 per cent starch-equivalent and concomittently improves also the quality of the beef considerably. If this starch equivalent surplus would be allotted to beef-cattle keeping, the beef output would lag considerably behind that level which can be attained by the current calving of beef-purpose heifers. Beyond this in case of special given conditions and demands, the keeping of beef-cattle may however likewise come into the foreground.

In the future the more extensive use of specialised types (milk- and beef), the faster breed- and type-change and the more wide-spread employment of combinative cross-breeding will have to be taken into consideration more extensively also in cattle breeding.

Efficiency of production in cattle-breeding is essentially more intricate than it is in general presumed. This is due mainly to the fact that efficiency and size of the individual production are not always the same as the trend in the productivity of the total population. This became evident in poultry raising and led e.g. to the necessity of separating - in broiler production - the male line from the female line. The first was put into the service of increasing the individual meat productivity, while the second line served the purpose of economic reproduction, utilizing at the same time the appropriate heterosis effect. The diverging interest between the integrated and specialized poultry breeders has a similar background. In cattle breeding, particularly the milk and beef production performed with the same population raises similarly a large number of unelucidated problems. Obviously this resulted in the divergences of opinions being very considerable, both in the question of type and body weight and as regards the direction of optimum utilisation, even in the so-called specialized 
breeding aimes (specialised beef- and dairy breeds). This situation is complicated by the need that the economically producing cow must have not only a considerable degree of efficiency in order to convert the feed into butterfat and milkprotein and to produce economically calves corresponding to the purposes of fattening but must likewise stand the test in the up-to-date mechanised establishments. The rentability of milk-production from the point of view of the cow is relatively well reflected by the quantity of milk produced, concentration of milk (Witrr, 63; Horn, 29; Biró, 4; MCDaniel, 49; Hofmann, 28; etc.), by the milk-yield related to live weight, which seems the safest index of food conversion for the practice (SUChANEK, 56; Dohy and Ludrowsky, I7, etc.) and even beyond this by the milk-production per one day of life related to the live weight, which is perhaps the most pregnant indicator for the efficiency of milk-production (DoHY, I6).

According to results of earlier researches (KRIZENECZkY, 38; Gowen, 26; TURNER, 59; LAUPRECHT and DöRING, 4I) the conception became wide-spread that Ioo $\mathrm{kg}$ increase of the cow live weight involves an about 300 to $600 \mathrm{~kg}$ additional milkproduction. This finding was subjected to revision by a few research workers (Johansson, 37; WiLK, Young and CoLE, 62). From more recent examinations in which the authors studied the correlation between live weight and milk yield, in populations of large numbers, producing under the same environmental conditions (e.g. Clark and Touchberry, i2; Bozó and Dunay, 7; Vasiljev and Startzen, 6r; VAN VLECK, 6o; MONOENOKV and VSJAKIH, 5I; BREITENSTEIN and FIEDLER, 9; Csomos, I4; ELSAIED, 23) the conclusion can be drawn, that a considerable increase in the milk-yield of cows cannot be hoped -for from an increase of live weight. It seems furthermore as if the concentrated milk-producing types would -related particularly to a live weight unit - easier produce economically. The outstanding relative productions, which are attained by concentrated milk producing breeds and individuals, specially related to the live weight unit, are pointing to this fact. In this connection I may point to the Danish Jersey, Finnish Ayrshire breeds, as also to the cow stocks of New-Zealand, etc. (Table I).

The hungarian results seem to confirm similarly that types producing a more concentrated milk - specially under conditions of large-scale farmingcan easier and with more security hold their leading position, than breeds or crossbreed populations producing more but less concentrated milk.

While indices of the efficiency of milk production are relatively well clarified, those referring to beef production or to a combination of the two are far more contradictory. This applies particularly to the integrated beef producing capacity of one population. The cause of this is that while in some phases of fattening good many indices or parameters have a positive effect, with regard to the total beef production of the population, the effect is negative. Already during the Congress at Edinbourgh HORN (3I) has presented a report on examinations concerning the milk- and beef production produced by Hungarian Flackvieh cows belonging to different weight categories, from the same nutrient quantity. The data have clearly shown already at that time that with growing cow live weight the total beef production of cow categories from 550 to $850 \mathrm{~kg}$ comes - just contrary to expectations - into a negative phase, particularly in relation of the 
TABLE I

Ratio per breed of cows attainig $3000 \mathrm{~kg}$ butterfatproduction in Denmark (1967/1968)

TABLEAU I

Proportion des vaches, qui, suivant les races, atteignent une production beurrière de $3000 \mathrm{~kg}$ au Danemark en I967/1968

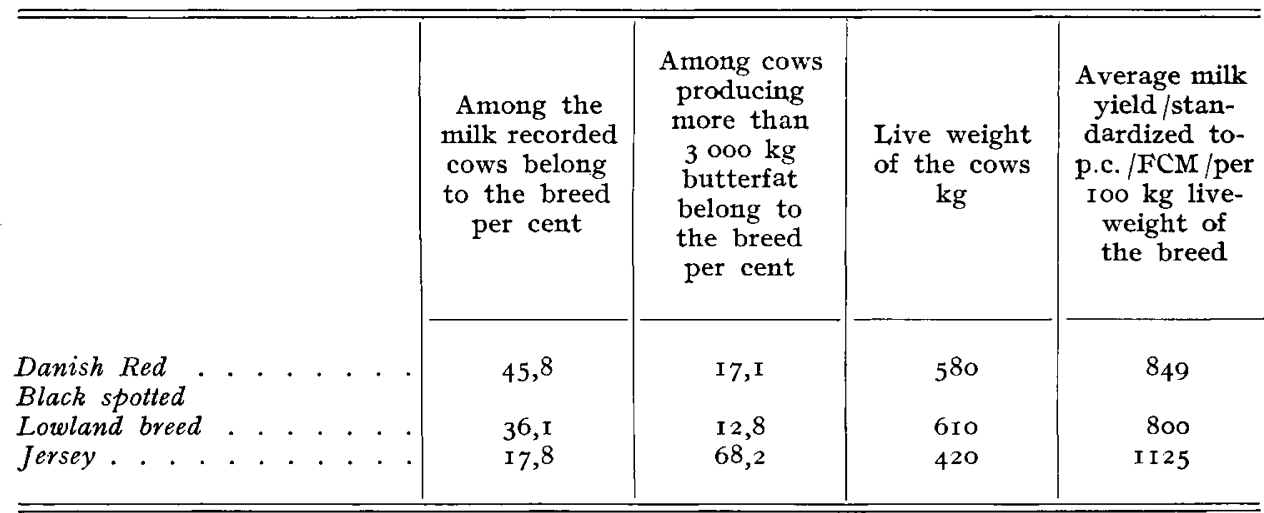

more valuable young beef. On the ground of these and other examinations it appears that it is more than probable, that the most economically producing cattle type may be fundamentally different from that which is qualified the best by the traditional conception.

In connection herewith it is particularly interesting to emphasize the daily growth-rate as one of the most important individual parameters of beef-production. Thus, e.g. a breed selection siming at a large daily gain in the interest of beef production is undoubtedly advantageous from the point of view of food conversion during fattening. At the same time however such a breeding aim - specially when fattening aims at a large final weight - may lead in general to heavier types which mature later.

The general opinion keeps a certain positive correlation in evidence between the live weight of parents and the weight gains of progenies. Parameters characteristic for some breeds point also into this direction, as well as results obtained during the different crossbreeding experiments (HORN, DUNAY, BOzó, 35; Szuromi, 58). Though this correlation - concerning its tendency - is reliable by all means, still a reciprocity within breeds between live weight of the parents and weight gain of their progenies could not be established: BAR-ANAN and LEVI (2), Brinks et al. (Io), Dunay (20), Szuromi (57), Marlove (47). This is probably due to the weight-categories not being separated genetically within the different breeds. The growing body weight related to a given feed growing area or to the same feed quantity, diminishes the number of produceable calves and contrary to the expectation reduces the beef-producing capacity related to the whole population. The loss resulting hetefrom may be occasionally larger than the profit which can derive from the utilization of cows of larger live weight so Nuch the more as according to our today's knowledges the most importantlimitingfactor 
of beef production is the number of calves which can be produced on the feed-unit (Fig. I).

Considerations of those shortly outlined above led to the set of experiments which we have conducted already hitherto and are going to perform also further on with the view to find out how during the utilization of populations of different body weight and type, the relation and profitability of butterfat, milk protein and beef production develop on the same quantity of feed. A very intricate mass of facts must be synthetized, before certain grades could be assigned to the different populations. At the same time we must share the opinion of those CoLE et al., 13), according to whom for instance neither in the field of beef-production do exist unequivocally ideal breeds. We would like to point out a few contradictions in this connection. The capacity of a high daily gain which is a fundamental character of economic beef-production, is in many cases manifested more superiorly in dairy breeds of a larger body (e.g. U.S.A. or Canadian Holsteins), than is specialised beef-breeds (COLE et al., I3; LINDHÉ, 46). In the same way the early maturity which in the earlier period of fattening usually result in a more favourable weight-gain and simultaneously in a faster rotation of the stock, impairs the rentability of beef production in case of fattening to a heavier weight. Neither the fattening to a heavier weight is a practicable road of rendering the beef production profitable, since almost twice as much feed is required per live weight unit, when fattening goes-on to $500-600 \mathrm{~kg}$ weight than quantity needed for fattening to 200-300 kg weight (NAGY, 52; LENSCHOw; STUNZ, OtTo, 43, etc.).

The carcass weight percentage is likewise regarded as an important beefproduction index. At the same time less developed respiratory and digestive organs are associated with a favourable carcass percentage. Therefore from the point of view of carcass waight percentage, exactly those types are pushed into the background which have the highest feed-uptake capacity and may be the best converting animals mainly in relation of milk-but also of beef production. This statement emphasizes similarly the necessity of a certain revision of the blocky and short, classical beef-cattle type, JoBst (36). We do not wish either to deal here with the beef quality in more detail, we point only to the heavier weight being in general accompanied with coarser fibres. Thus it could occur that in different taste and qualification tests (FLOCK, 24; EDGAR, 2I, etc.) the beef of precisely those breeds proved the best which from fattening and meat industrial points of view, obtain the lowest grading in general. Quality of the beef is a function far more of feeding, degree of fatness, age and state prior to slaughterage of the animal, then of the breed.

Considerable importance is attributed also to the beef-conformation, which are decisive particularly in the selection of sires, of dual-purpose breeds, though beef-conformation is in no close correlation with either the daily growth-rate or with some other characters (BALIKA, I; DUMONT, I9; HARING, 27; LANGLET, GRAVERT, ROSENHAHN, 40). At the same time the beef-conformation judged as favourable and the increasing width-measures may lead to the tainted inheritance of calving difficulties.

The shortly outlined characters determine jointly the beef-producing capacity of the individuals and their value for the meat industry. On the other hand 


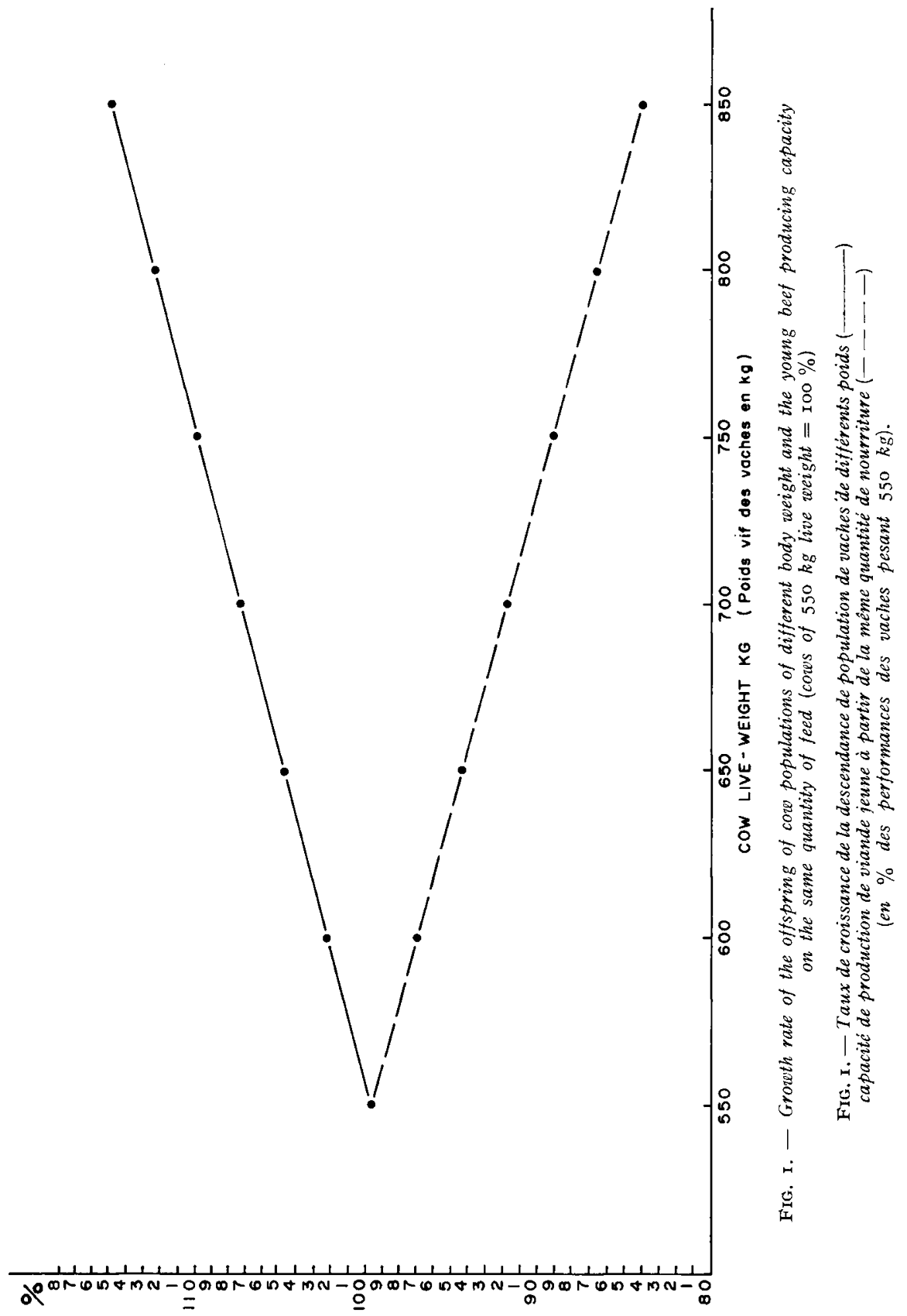


TABLE 2

Product outputs of cattle populations of different live weights and individual production characters

TABLEAU 2

Rendements de populations bovines de différents poids vits et de caractéristiques productives différentes

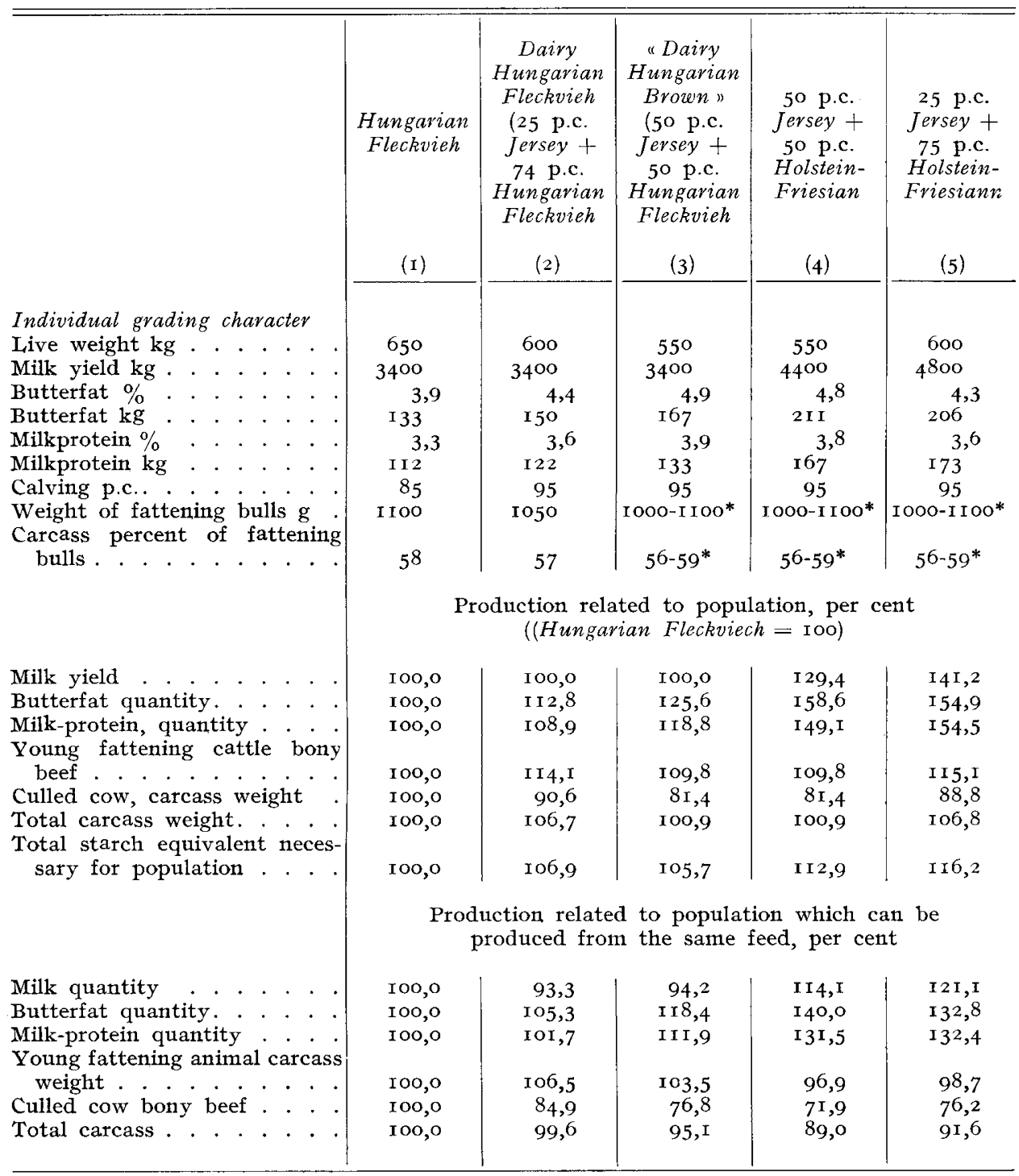

Denomination: 33 per cent of the cow-stock of 3-4-5 populations are fertilized with Charolais. Production data of 4-5 populations have been established with genetical calculation.

* farm animals. 
in relation to whole cattle populations the beef-producing capacity of a stock is determined by the question: with which stock more milk and beef can be produced from the same nutrient quantity? From such point of view several kinds of possibilities are offering themselves, commencing from the classical dualpurpose breeds to the specialized breeds, in some cases with the inclusion of utility-crossing.

In order to illustrate the effect of individual grading characters, displayed on production related to population, let us present five cattle populations, having different individual grading characters used in our evaluations (Tab1. 2).

In our days one of the most serious problems in cattle breeding of Europe is undoubtedly to create a differencial balance of milk- and beef production for the good of beef. This has biological reasons in part, but national economy causes in the first place. The presently still almost generally prevailing breeding tendency sees the breeding ideal in dual-purpose breeds which after certain possibilities are made use off leads lawfully to the formation of milk surpluses and to beef shortage. This may be traced back to a fundamental rentability interest of the breeder being linked with the increase of milk-yield per cow. Having in view that the uptake capacity of the milk market is limited it is comprehensible that an increase of milk-yield per cow is associated with the reduction of the cow-numbers. On the other hand this has grave consequences, since the number of calves is a limiting factor which basically is a function of cow number and fertility (HORN, 32; CZAKó, I5; KRÜGER, 39; BEDö, 3). This in part turns the attention increasingly to the development of beefcattle keeping (SCHNitTEN, 54) and raises on the other hand the necessity of breeding methods such as commercial crossing, possibilities of inducing twin-calvings (EDWARDS, 22; CARMAN, II) which previously have been barely dealt with by researchers.

In our experiments, where we performed commercial cross-breeding with Hereford and Charolais bulls in a "dairy Hungarian brown" population, of 50 per cent Jersey generatio, - beyond the considerable improvement of beefconformation and marketability - an about 6 percent surplus appeared also in beef-production (HoRn, Dunay, Bozó, 35), which though regarded in itself, is important, still does not yet solve the formation of such a ratio of milk-and beef-production, which corresponds to the market demands.

To increase the beef production (Bozó, DUANy, DEAK, 8) in dairy-type stocks commercial crossbreeding is performed with Hereford bulls, extend to all heifers and to 30 per cent of the cow-stock. The born heifer of beef-bull paternity is fertilized at young ( $\mathrm{r} 4-\mathrm{I} 5$ months old) age with a Hereford bull and after claving (in about 24-25 months of age) followed by one month fattening, the once calved young cow is marketed for slaughterage. According to calculations, related to Ioo cows, with this method, the output of valuable young beef can be increased with about 44 per cent -against about 14 per cent surplus of starch equivalent, compared to the result when we would not have carried out in the stock the commercial cross-breeding and would not have made the heifers of beef-bull paternity to re-calf again (Table 3 ).

This method - to which the results published by Mescal (50) and RosTOVZEV (53) are the nearest - enables us to rationally increase the calf-number 
produceable by the population and through this the beef production per one cow of the population.

The question may be raised in connection herewith, wether it would not be more purposeful to manage one-purpose beef cattle on the surplus feed required for the re-calving of beef-purpose heifers? According to our calculations, illustrated on figure 2 , the young fattening-animal-live-weight production of the population is less than the beef production realizable in the case of re-calving of the meat-purpose heifers. It should be noted however that the beef-increase

\section{TABLE 3}

Trend of milk and beef production in three populations having the same cow population but in which different breeding methods have been employed

\section{TABLEAU 3}

Tendance de la production laitiève et beurrière

dans trois populations originaires au départ de la même souche maternelle mais sur lesquelles on a pratiqué différents types de croisements

Yield and starch equivalent- requirement of the population in percentage of flrst population

\begin{tabular}{|c|c|c|c|}
\hline & I st population & 2 st population & 3 rd population \\
\hline Milk (kg) & 100,0 & Ioo,o & IOo,o \\
\hline 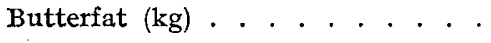 & 100,0 & IOO,O & 100,0 \\
\hline Milk protein $(\mathrm{kg})$. & I OO,O & IOO,o & IOO,o \\
\hline 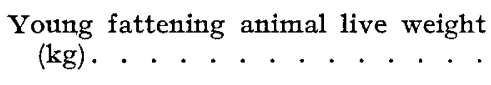 & 100,0 & $106, \mathbf{I}$ & r 43,9 \\
\hline Culled cow, live weight $(\mathrm{kg}) . .$. & 100,0 & 100,0 & IOO,O \\
\hline 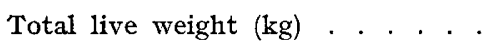 & 100,0 & IO 4,6 & 132,8 \\
\hline 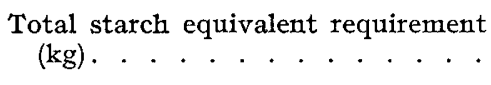 & 100,0 & 99,9 & I I 4,3 \\
\hline
\end{tabular}

Ist population : Cow population of $50 \%$ Jersey and $50 \%$ Hung. Fleckviech.

2nd population: Thirty per cent of the cows of the Ist population and the total heifer stock were fertilized with Hereford semen.

3 rd population: The total heifer stock and 30 per cent of the ist population were fertilized with Hereford. The heifers sired by Hereford are once more fertilized with Hereford at young age, and after calving are marketed as young beef-cows.

produceable by means of re-calving the beef-purpose heifers cannot exceed the already mentioned 40 to 50 percent, therefore for a satisfaction of a higher claim than this the management of beef-cattle seems justified, provided adequate conditions are given. 
This methods provides possibilities of an increased beef production without augmenting the number of stalls in the dairy farm, which require heavy investments, so that through this the rentability of the production of basic materials for fattening can be largely improved. It is advisable to follow this breeding procedure in the firts place with using early maturing populations. This sexual

FIG. 2. - Young beef producing ability $\%$ of cow populations of equal milk production by using different breeding methods $(A$ population $=$ roo $\%)$.

FrG. 2. - Capacité de produire de la viande jeune de différentes population de vaches ayant des productions laitières identiques (en $\%$ des performances de la population A).
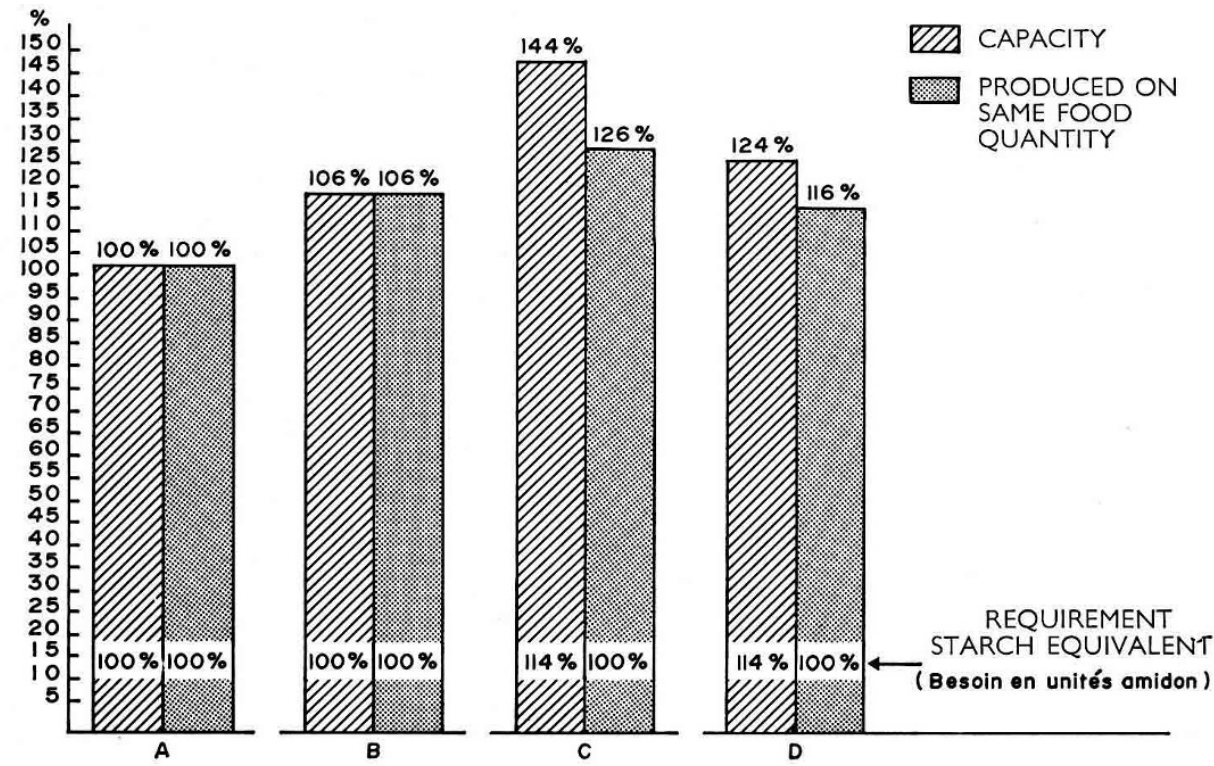

Population A: $50 \%$ Jerscy $+50 \%$ Hungarian fleckvieh.

Population B: All the heifers and $30 \%$ of the cows inseminated with semen of Hereford bulls.

Populatiou C: All the heifers and $30 \%$ of the cows inseminated with hereford semen the young $F_{1}$ heifers again with hereford semen and slaughtering them after giving birth to the calf.

Population D: All the heifers and $30 \%$ of the cows inseminated with hereford semen and keeping beef cattle (hereford cows) on the surplus feed (I $4 \%$ of the C/Population).

early maturity is necessary also for the reason because -in addition to the speeding-up of rotations- only thus can be attained that development, growth of the heifer and the building-up of pregnancy should fall into one period and the building-up of the fœtus, from the point of view of weight gain, should not come into an inactive stage.

Thorough further investigations are required to allow the establishment of that type of cattle which according to special given conditions, is the most productive. It should be carefully considered that under certain conditions the female line is to be separated from the male line, not only in the dairy stocks but within beef cattle as well. In this way the production linked to the female sex (milk yield, calf production, early maturity) may take place with favourable 
conversion, while the characters connected with fattening (weight-gain, slaughter value) may be ensured through the male lines. It would be advisable to liberate the minds of prejudice and revise our breed-targets form time to time. It may be that in spite of the slow generation interval we must prepare ourselves in cattle breeding to a faster type- and breed change, in the same way which is already common in plant production but is an every increasingly spread phenomenion in other branches of animal production as well. During this course we shall have to make use also of those gene reserves which have been disclosed somewhere in the world. Jointly with an intensive purebreeding at a high level, this process will push the combinative crossbreeding likewise into the foreground.

Reçu pour publication en décembre 1970 .

\section{RÉSUMÉ}

\section{L'INFLUENCE DE LA TAILLE ET DU TYPE SUR LE RENDEMENT EN LAIT} E'T EN VIANDE CHEZ IES BOVINS

A partir de leurs propres recherches et de la synthèse des résultats de la littérature spécialisée, les auteurs ont analysé l'incidence de la taille corporelle et d'autres critères de jugement individuel des bovins sur la production totale au niveau de la population.

Selon eux, l'efficacité ou le niveau de production individuel ne permet pas toujours de prédire la productivité totale de l'ensemble de la population. Ainsi la sélection en vue d'une forte vitesse de croissance, avantageuse du point de vue de la transformation alimentaire chez l'individu, peut conduire à la création de souches de vaches à poids élevé, avec l'éventualité d'une décroissance des quantités de viande, de veaux ou de lait fournies pour une même quantité d'aliment.

Si l'on examine la relation entre taille corporelle et production laitière dans des populations d'une même race, placées dans des conditions de milieu homogènes, ce qui n'était pas le cas dans la plupart des recherches antérieures, il n'apparaît pas de liaison importante entre les deux caractères. De même, pour une race donnée, une liaison substantielle entre la taille des parents et la production de viande de leur descendance ne peut pas être mise en évidence. Cela pourrait provenir de ce que des différences de poids vif ne traduisent pas des différences génétiques, à l'intérieur d'une même race. En conséquence, à partir d'une certaine limite, on ne peut pas attendre d'augmentation intéressante de la production de viande ou de lait, d'un accroissement du format.

Tandis que dans le cas de la production laitière, les productions au niveau de l'individu et de la population dépendent de façon assez claire des caractères individuels (quantité de lait, taux butyreux, taux de protéines, etc.) la situation est plus complexe dans le cas de la production de viande. La production de viande chez les bovins et particulièrement sa rentabilité est fonction de très nombreux caractères. La sélection visant à améliorer des caractères de qualité typiquement individuelle (vitesse de croissance, indice de consommation, rendement boucher et conformation, qualité de viande) n'améliore pas indubitablement la capacité globale de production de viande au niveau de la population. Cette dernière est déterminée d’abord par le nombre de vaches et leurs qualités de reproduction.

Il est possible, sans grandes difficultés, de sélectionner en vue de la production laitière et d'améliorer en même temps la production de viande et, d'autre part ce n'est pas à partir de la seule augmentation du rendement laitier individuel dans les races mixtes qu'on pourra ajuster les productions de lait et de viande aux besoins du marché.

La méthode que suggèrent les auteurs semble utile pour une augmentation sinultanée de la production de lait et de viande, spécialement de cette dernière. Il s'agit principalement de faire appel à des taureaux de race à viande, à maturité précoce, pour les croiser aux vaches de types laitier, à bonne précocité sexuelle. Les mâles croisés sont vendus après engraissement; les génisses croisées sont inséminées très tôt avec des taureaux à viande et sont abattues comme jeunes vaches, un mois après vêlage. Après un cycle complet, le poids vif de jeunes bovins vendus par vache laitière augmente de 44 p. 100 , alors que la consommation d'unités amidon n'augmente que de 14 p. 100 et que la qualité bouchère s'améliore considérablement. Si ce surplus alimentaire avait été affecté à des bovins de race à viande spécialisée, la production de viande 
se situerait nettement en-dessous. Dans des conditions spéciales et selon la demande, l'intérêt de troupeaux de race à viande peut, de la même façon, apparaître au premier plan.

Dans le futur, l'amélioration des bovins nécessitera de prendre plus en considération une plus large utilisation des races spécialisées (lait ou viande), un changement plus rapide des races et types et un emploi plus étendu des possibilités de complémentarité offertes par le croisement.

\section{REFERENCES}

(r) Balika S., x968. Allattenyésztés, Budapest, 17, (2).

(2) Bar-ANan, R., I.Evi, U., I963. E.A.A.P. Symposium, Roma.

(3) Bedó S., I967. A grartud. Fóisk. Kiadv. Keszthely, 9, (1 I).

(4) BrRó (Gy.), 1966. Allattenyésztésünk utja a világszinvonal felé, Mg. $\mathrm{K}$.

(5) Bozó S., 1967. Mg. Vilagirodalom, 9, 517-519.

(6) Bozó S., Dunay A., r97o. DEAK M. : Allattenyésztés, 9, r5-27.

(7) Bozó S., 1968. Mg. Világirodalom, Budapest, 10, 515-518.

(8) Breitenstein, K. G., Fiedler H., 1968. Archiv. f. Tierz., 11, 37-5r.

(9) Brinks J. S., Clark R. T., Kieffer N. M., Quessenberry J. R. J. Anim. Sci., 21, 777-78o.

(ro) Carman, G. M., r969. J. Anim. Sci., 28, ri6-r23.

(i I) Clark R. T., Touchberry R. W., 1962. J. Dairy Sci., 45, I500-I5Io.

(12) Cole J. W., Ramsey C. B. et al., 1964. J. Dairy Sci., 7, II38-ir44.

(13) Csomós Z., I969. Kand. diss., Budapest, M'TA.

(15) Czakó J., 1967. Sotto gli auspici della Fiera Campionaria Internationale di Milano. I4-I5-I6. Aprile, I65-I69.

(г6) DoHy J., I967. Kand. diss., Budapest, MTA.

(ry) DOHY J., I,UdRowsky F., r966. MTA IV. Oszt. Közl., 25, 309-314.

(18) DREYeR D., SMIDT D., I966. Tierzüchter, Hannover, 18, 528-529.

(r9) Dumont B., 1965. Wrd. Rev. Anim. Prod., 1, 25-29.

(20) Dunay A., 1967. Diss. Gödöllö.

(21) EDGAR D., I966. Fmr. Stk-Breed., London, 80, (3993), 59-6r.

(22) Enwards J., 1965. Wrd. Rev. Anim. Prod., 1, 13-21.

(23) Elsaied M. A. E., I968. Kand. diss., Budapest, MTA.

(24) FLock D., I962. Züchtungskunde, 34, 296-306.

(25) Gowen J. W., 1925. J. Agric. Res., 30, 865-869.

(26) HARING F., I967. Züchtungskunde, 39, 432-443.

(27) Hofmann G., 1966. Tierzüchter, Hannover, 18, 490-49r.

(28) HoRN A., 1962. MTA Agr. Tud. Oszt. Käzl., 21, I-I7.

(29) Horn A., 1965. Acta $A g r .$, Budapest, 14, I55-I77.

(30) HoRn A., I966. Proc. 9th International Congress of Animal production, Edinbourgh, I68.

(3I) Horn A., 1967. Wrd. Rev. Anim. Prod., 3, 34-35.

(32) HORN A., r969. Tierzüchter, Hannover, 21, 505-507.

(33) Horn A., Dohy J., 1969. Wiss. Z. Humboldt Univ., Berlin, 18, r 85-193.

(34) Horn A., Dunay A., Bozó S., r968. "Tejelö magyar barna "állomány hustermelésének javitása hereford és charolais fajták felhasználásával, Budapest, 1968. AKI Évkönyve, Zárójelentés.

(35) Joвst D., 1970. Winter Conference Cambridge, Brittish Cattle Breeders'Club, Isfield, 25, 85-93.

(36) Johansson J., 1964. Anim. Breed. Abst., 32, 42 I-433.

(37) KRIZENECzKy J., I94I. Z. Tierz. Zücht Biol., 51, xоo-xI7.

(38) KRüGER I.., 1966. Züchtungskunde, 38, 23-27.

(39) I.ANglet J. F., Gravert H. O., Rosenhahn E., 1967. Z. Tierz. Zücht Biol.,83, 358-370-.

(40) LaUprecht E., DörING H., Milchwissenschaft, 5, 383-389, 4I6-4I8.

(4I) Legates J. E., I966. Wrd. Rev. Anim. Prod., 2, 69-76.

(42) L.enschow J., Stunz H., Otтo E., r969. Tierzucht, Berlin, 22, 310-3г3.

(43) LeUthold G., Wilke A., r969. Wiss. Z. Humboldt-Univ., Berlin, 18, 205-220.

(44) Levantin D., I966. Szoverzsensztvovanie porod krupn ogo rogatogo szkota. Moszkva " Kolosz ", 26I-274. 
(45) I.INDHÉ B., I964. Tierzüchter, Hannover, 16, 308-310.

(46) Marlove J., I962. J. Anim. Sci., I962, 21, 974.

(47) Mason J. I., r966. Anim. Breed Abst., 34, 453-473.

(48) Macdaniel B. T., I965. Diss. Abstr., 26, 588-589.

(49) Mescal A. A., I970. The Farmer and the Beef Industry., E.A.A.P. Symposium Roma.

(5I) Manoenkov M. J., Vszjakih A. Sz., Trudu V. I. Zs. A., I966. Moszkva Kolosz, r966, 28.

(52) NAGy N., I966. Kand. diss, Budapest, MTA.

(53) Rosztovcev N. F., r969. Tierzüchter, Hannover, 21, r94-196.

(54) Schönmuth G., I966. Wiss. Z. Humboldt. Univ., Berlin, 15, 369-376.

(55) Schmiten F., I969. Tierzüchter, Hannover, 21, I94-196.

(56) Suchanek B., r963. Ziv. Vyr., Praha, 8, 389-398.

(57) Szuromi A., I967. AKI. Évkonyve, Budapest.

(58) Szuromi A., I969. Magyartarka hustermelésének összehasonlitó vịzsgálata. AKI Évkönyve, Budapest, Zàrojelentés.

(59) Turner C. W., r93o. Res. Bull. Mo. Agric. Exp. Sta., (147), 42.

(6o) Van Vleck D., I964. Hoard's Dairyman, 109, I46.

(6r) Vasziljev R. P., Sztarcev D. I., I966. Trudii V. I. Zz. A., Moszkva, Kolosz, 28.

(62) Wrtr M., r965. Die Einstellung der Veredlungswirtschaft auf die Anforderungen der EWG. MaxPlanck Inst., Mariensee. 